\title{
SLAUGOS STUDENTŲ PROFESINĖJE PRAKTIKOJE PATIRIAMAS STRESAS IKI COVID-19 PANDEMIJOS IR JOS METU
}

\author{
Viktorija Piščalkienė, Lijana Navickienė \\ Kauno kolegija, Medicinos fakultetas
}

Raktažodžiai: stresas, koronaviruso pandemija, Covid-19, slaugos studentai, profesinès praktikos.

\section{Santrauka}

Tyrimai rodo, kad slaugos studentai profesinių praktikų metu patiria nuo vidutinio iki didelio stiprumo stresą. Nors stresas yra normali reakcija ị daugelį aplinkybių, tačiau jo poveikis gali būti žalingas sveikatai, mokymosi rezultatyvumui, studentų savivertei ir motyvacijai tęsti slaugos studijas.

Tyrimo tikslas - palyginti slaugos studentų streso priežastis profesinių praktikų metu iki COVID-19 pandemijos ir jos metu.

Tyrimo objektas ir metodai. Tyrimo tikslui pasiekti vykdyti du tyrimai. Pirmasis vyko prieš COVID-19 pandemiją (2019 metų lapkričio ir gruodžio mèn.). Antrasis - Covid-19 pandemijos metu (2020 metų lapkričio ir gruodžio mèn.). Rinkti kiekybiniai ir kokybiniai duomenys. Tyrimo priemonè apima tris stresorių sritis: 1) profesinès praktikos organizacinès sąlygos; 3 ) bendravimas; 4) situacijos, susijusios su koronaviruso infekcija ir jos valdymu (vertintos tik antrojo tyrimo metu).

Kokybiniai duomenys rinkti pateikiant studentams atviro tipo klausimą apie profesinių praktikų teigiamas ir neigiamas patirtis, kurias galima apibūdinti kaip sąlygas, mažinančiais ar didinančias stresą.

Tyrime dalyvavo koleginio sektoriaus bendrosios praktikos slaugos studijų programos studentai. Iš viso tyrime dalyvavo vienos Lietuvos kolegijos bendrosios praktikos slaugos studijų programos antro, trečio ir ketvirto kurso 290 studentu. Tyrimas buvo vykdomas du kartus.

Rezultatai. Slaugos studentų stresas yra dažnas reiškinys, susijęs su ịvairiomis organizacinėmis profesinių praktiku situacijomis, bendravimu su personalu ir pacientais. Šios streso priežastys vienodai aktualios buvo iki koronaviruso pandemijos ir per ją. Pandeminiu laikotarpiu stresą kèlè situacijos, tiesiogiai susijusios su koronaviruso pan- demija: ignoruojamas slaugytojų vaidmuo socialinėse medijose bei baimè užsikrèsti koronavirusu.

Kokybinių duomenų analizè išryškino teigiamas ir neigiamas profesinių praktikų situacijas, kurios yra ypač svarbios slaugos studentų psichosocialinei adaptacijai ir profesinių kompetencijų igijimui praktinio mokymo metu realioje darbo vietoje. Teigiamos situacijos: pasitikèjimas studentais ir jų pripažinimas, mentorių ir kitų darbuotojų dèmesys ir mokymas, galimybè atsakingai dirbti ir išmokti, pacientų dèkingumas ir pasitikèjimas studentais, galimybė padèti žmogui ir pagerinti jo sveikatą. Slaugos studentų dažniausios neigiamos situacijos buvo šios: akistata su pacientų mirtimi ir sunkiai sergantys pacientai, personalo nepasitikejjimas studentais, menkinimas, baimè, susijusi su COVID-19 liga.

\section{Ivadas}

Profesinis stresas - reiškinys, su kuriuo susiduria tiek sveikatos priežiūros įstaigose dirbantys specialistai, tiek sveikatos mokslų studentai profesinių praktikų metu. Slaugą studijuojantys studentai lygiai pusę studijų laiko praleidžia realioje praktikos vietoje. Didele tikimybè, kad būsimi slaugytojai profesinių praktikų metu patirs tas pačias stresą sukeliančias situacijas, kurias patiria ir slaugytojai praktikai.

Praktinis mokymas - slaugos studijų dalis, realizuojama realioje profesinejje aplinkoje, pagrịsta aiškia dokumentine baze, praktinèmis situacijomis, studentų kritiniu mąstymu [1]. Tyrimai rodo, kad slaugos studentai profesiniu praktikų metu patiria nuo vidutinio iki didelio stiprumo stresą. Stresas siejamas su procedūrų atlikimu, technologijų ir įrangos naudojimu, konfliktiniais santykiais su personalu, pacientais ir jų artimaisiais [2-7]. Tyrimai rodo, kad netgi praktinio mokymo vieta turi ịtakos slaugos studentų streso raiškai. Pavyzdžiui, profesinès praktikos neonatologijos skyriuose studentų buvo ìvardytos kaip vienos iš labiausiai stresą kèlusių praktikos vietų. Dažniausiai įvardijamos priežastys buvo naujagimių maudymas bei injekcijų atlikimas naujagimiams [8]. Stresi- 
nès situacijos, kurias išgyvena slaugos studentai intensyviosios terapijos skyriuose, dažnai susijusios su paciento staiga blogejjančiais gyvybiniais pokyčiais, netikèta mirtimi [9].

Stresą profesinių praktikų metu didina netinkamu bendravimu ir bendradarbiavimu gristi santykiai tarp studento ir praktikos vadovo bei personalo $[6,10]$.

Pasaulį užklupus koronaviruso pandemijai (COVID-19), sveikatos priežiūros specialistai ir gydymo ịstaigose praktikas atliekantys studentai patenka tarp asmenų, kurių didesnè rizika patirti stipresnes reakcijas ị pandemijos metu patiriamą stresą.

Covid-19 pandemija turejjo įtakos slaugos praktikos pokyčiams. Tyrimai rodo, kad koronaviruso pandemijos metu slaugos studentų streso raiška yra didele [11,12]. Covid-19 pandemijos metu slaugos studentu stresas buvo siejamas su baime užsikrèsti koronoviruso infekcija ar šią infekciją perduoti savo šeimos nariams [13].

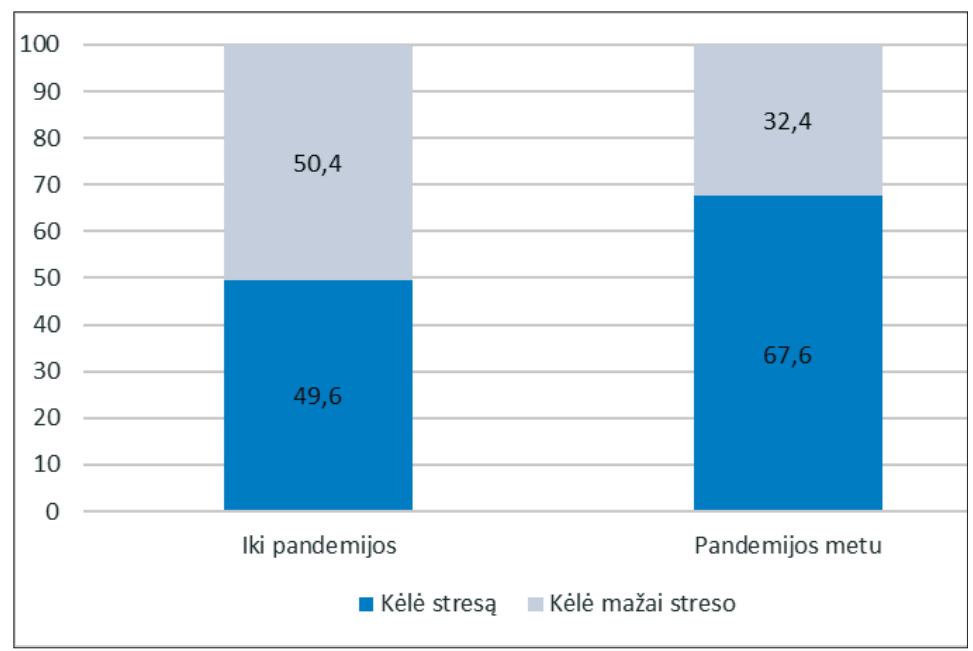

1 pav. Slaugos studentų patirtas stresas profesinių praktikų metu iki pandemijos ir pandemijos laikotarpiu $(\mathrm{N}=290)$

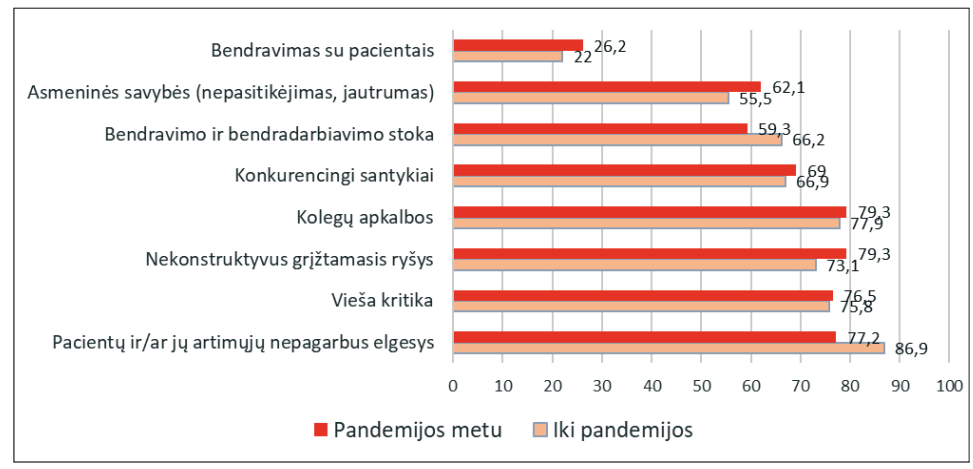

2 pav. Bendravimo sąlygos, turejjusios įtakos slaugos studentų stresui profesinių praktikų metu $(\mathrm{N}=290)$
Lietuvoje kol kas stokojama tyrimų, padedančių atskleisti būsimų slaugytojų patiriamo streso raišką profesinių praktikų metu. Nors stresas yra normali reakcija ị daugeli aplinkybių, tačiau jo poveikis gali būti žalingas sveikatai, mokymosi pasiekimams ir motyvacijai tęsti slaugos studijas. Ankstyvas streso požymių pažinimas, savalaikių ir tikslingų metodų taikymas - priemonès, leidžiančios išlaikyti saugią socioedukacinę aplinką realioje praktikos vietoje, kuri skatintų pažintinius ir asmenybinius studentų gebejjimus ir tinkamai padètų pasiruošti profesinei karjerai.

Tyrimo tikslas - palyginti slaugos studentų streso priežastis profesinių praktikų metu iki COVID-19 pandemijos ir jos metu.

\section{Tyrimo objektas ir metodai}

Tyrimo tikslui pasiekti rinkti kiekybiniai ir kokybiniai duomenys. Tyrimo priemoneje pateikti klausimai apima tris stresoriu sritis: 1) profesinés praktikos organizacinès sąlygos; 3 ) bendravimas; 4) situacijos, susijusios su koronaviruso infekcija ir jos valdymu (buvo vertinama tik antrojo tyrimo metu).

Kiekybiniai tyrimo duomenys buvo apdoroti taikant aprašomąą statistiką ir statistinę duomenų analizę ( $\mathrm{T}$ testą, Anova testą, Chi kvadratą). Cronbach alfa skalès teiginių lygmeniu siekè 0,91.

Kokybiniai tyrimo duomenys rinkti pateikiant studentams atviro tipo klausimą apie profesinių praktikų teigiamas ir neigiamas patirtis, kurias galima apibūdinti kaip sąlygas, mažinančiais ar didinančias stresą.

Tyrime dalyvavo koleginio sektoriaus bendrosios praktikos slaugos studijų programos studentai. Iš viso tyrime dalyvavo vienos Lietuvos kolegijos bendrosios praktikos slaugos studijų programos antro, trečio ir ketvirto kurso 290 studentų. Tyrimas buvo vykdomas du kartus. Pirmasis tyrimas vyko prieš COVID-19 pandemiją (2019 metų lapkričio ir gruodžio mèn.). Antrasis - Covid -19 pandemijos metu (2020 metų lapkričio ir gruodžio mèn.). Abiejuose tyrimuose dalyvavo po 145 bendrosios praktikos slaugos studijų programos studentus.

\section{Tyrimo rezultatai}

Tyrimu buvo siekta išsiaiškinti slaugos studentų profesinès veiklos praktikoje patirtą stresą iki Covid-19 pandemijos ir jos metu (1 pav.).

Covid-19 pandemijos metu slaugos studentuc patirtas stresas profesinių praktikų metu buvo didesnis, nei iki pandemijos $(\mathrm{p} \leq 0,05)$. Iki pande- 
mijos atliktos profesinès praktikos metu didesni stresą patyrè 49,6 proc. slaugos studentų. Pandemijos metu atlikto tyrimo rezultatai parode, kad toki stresą profesinès praktikos metu patyrè kur kas daugiau tiriamujų $(67,6 \%)$.

Negauta statistiškai reikšmingų skirtumų, leidžiančiu teigti, kad slaugos studentai iki Covid-19 pandemijos profesinių praktikų metu patirdavo mažesnį stresą, kurị kèlè bendravimo sąlygos (2 pav.). Iki pandemijos daugiausia slaugos studentuc $(86,9 \%)$ nurodè, kad jiems stresą kèlè pacientų ir jų artimujų nepagarbus elgesys. Pandemijos metu studentai mažiau pritare šiam teiginiui. Viena iš priežasčiu galèjo būti ribotas artimujų patekimas ì gydymo įstaigas dèl karantino sąlygų. Abieju tyrimų metu gauti rezultatai leidžia teigti, kad slaugos studentams labai svarbus pozityvus personalo požiūris ị juos. Daugiau kaip 2/3 tyrime dalyvavusių slaugos studentų nurodè, kad vieša kritika, nekonstruktyvus grị̌tamasis ryšys, kolegų apkalbos yra veiksniai, keliantys stresą profesinių praktikų metu. Bendravimo procesas su pacientais slaugos studentams nekèlè streso iki pandemijos ir pandemijos metu. Tik 22 proc. slaugos studentu iki pandemijos ir 26,2 proc. pandemijos metu bendravimą su pacientais pažymèjo kaip profesinių praktikų streso priežastị.

Negauta statistiškai reikšmingų skirtumų, rodančių, kad organizacinès sąlygos Covid-19 pandemijos metu turejo didesnę įtaką slaugos studentą stresui, nei iki pandemijos ( $\mathrm{p} \geq 0,05)$. Daugiausia slaugos studentų stresą kèlusių organizacinių priežasčiu susijusios su didele užduočių aprèptimi. Šios priežastys buvo vienodai aktualios iki pandemijos ir Covid-19 pandemijos metu (3 pav.). Padidejjęs darbo krūvis iki pandemijos kèlè stresą 87,5 proc. slaugos studentų ir 84,2 proc. studentų pandemijos metu. Neplanuoti ir skubūs darbai stresui įtakos turejo iki pandemijos 82,1 proc. ir 77,2 proc. slaugos studentų pandemijos metu. Personalo trūkumas taip buvo svarbi studentų streso priežastis iki pandemijos $(90,3 \%)$ ir pandemijos metu (89,7 \%). Galima manyti, kad dèl personalo trūkumo studentai patiria daugiau neigiamų situacijų, skiriamas mažesnis dèmesys jų adaptacijai naujoje būsimoje profesinèje aplinkoje, studentai mažiau gauna konsultacijų iš slaugytojų praktikų. Beveik 4/5 slaugos studentų nurodè, kad padidèjęs pacientų skaičius ir slaugos priemonių trūkumas jiems kelia stresą profesinių praktikų metu.

Per koronaviruso pandemiją slaugos studentams stresą kèlè socialinèse medijose ignoruojamas slaugytojų vaidmuo, kadangi sunkiomis koronaviruso pandemijos sąlygomis buvo
Padidèjęs pacientu skaičius

Slaugos ir kt. priemonių stoka

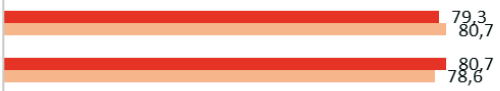

olatiniai pokyčiai praktikos vietoje

Ataskaitu, dokumentu pildymas

Personalo trūkumas

Neplanuoti ir skubūs darbai

Padidèjęs darbo krūvis
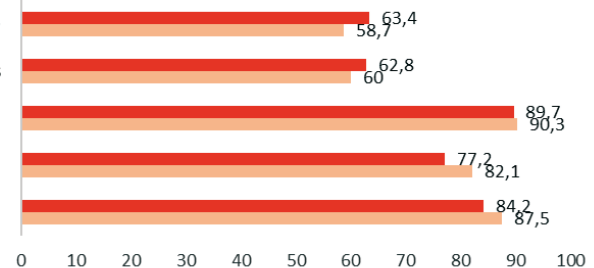

a Pandemijos metu Iki pandemijos

3 pav. Organizacinès sąlygos, kèlusios slaugos studentų stresą profesinių praktikų metu $(\mathrm{N}=290)$

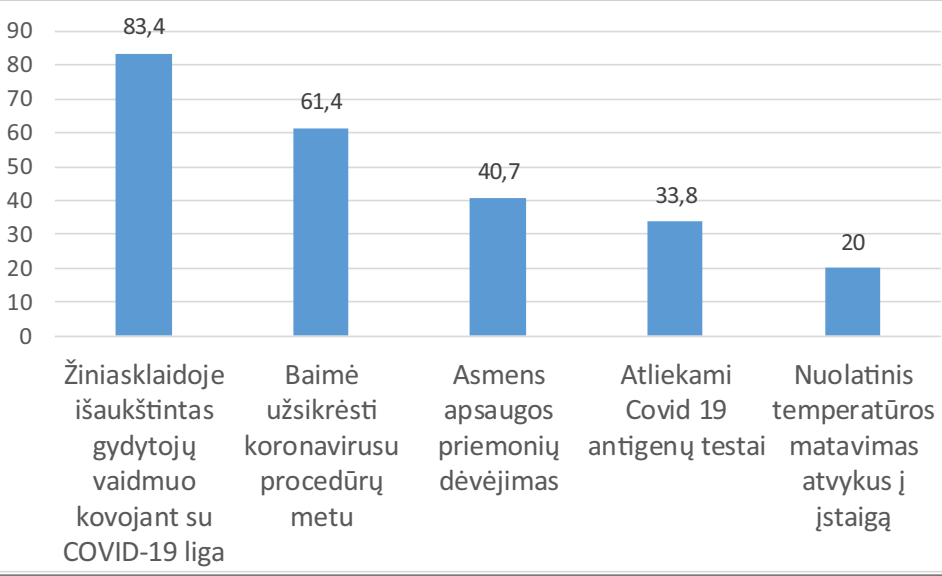

4 pav. Su koronaviruso infekcija ir jos valdymu susijusios situacijos, kèlusios laugos studentams stresą profesinių praktikų metu $(n=145)$

išskirtinai išryškinamas tik gydytojų vaidmuo. Tam pritarẻ 83,4 proc. slaugos studentų. Beveik 2/3 tyrime dalyvavusių slaugos studentų $(61,4 \%)$ nurodè, kad jiems didelị stresą kèlè baimè procedūrų metu užsikrèsti koronavirusu. Mažiau nei pusei tyrime dalyvavusių slaugos studentų stresą kèlè asmens apsaugos priemonių dèvèjimas, trečdaliui - atliekami PGR tyrimai koronavirusui nustatyti (tuo laiku nebuvo vakcinų ir studentai nebuvo imunizuoti vakcinomis nuo koronaviruso infekcijos). Mažiau nei ketvirtadaliui - nuolatinis temperatūros matavimas atvykus ị praktinio mokymo ịstaigą (4 pav.)

Atlikta kokybinių duomenų turinio analizè išryškino teigiamas ir neigiamas profesinių praktikų situacijas. Tos pačios situacijos išryškejjo tiek tyrimo, atlikto prieš Covid-19 pandemiją, tiek ir jos metu, todèl pateikiamos bendrai (1 ir 2 lentelès). Antrojo tyrimo metu, vykdyto Covid-19 pandemijos metu, išryškejjo koronaviruso infekcijos sukelti iššūkiai (2 lentelè).

Teigiamos situacijos susijusios su pasitikèjimu studentais, sąlygų sudarymu jiems dirbti savarankiškai, psichologine ir 
1 lentelè. Teigiamos slaugos studentų patirtys profesinių praktikų metu.

\begin{tabular}{|c|c|c|}
\hline Kategorijos & $\mathbf{N}$ & Autentiški pasisakymai \\
\hline $\begin{array}{l}\text { Pasitikèjimas studentais } \\
\text { ir galimybė dirbti sava- } \\
\text { rankiškai }\end{array}$ & 40 & $\begin{array}{l}\text { „,Slaugytoju pasitikèjimas mano atliktu darbu“. } \\
\text { „Darbo pasiūlymai bei praktikos stebèjimas kaip ieškant naujo komandos nario“. } \\
\text { „Pelneme pasitikejjima, net atsiuntè padèkos laiška praktiku vadovui. Bet kuriuo atveju reikia büti } \\
\text { mandagiam, paslaugiam, domètis tuo ka darai“.. } \\
\text { „Labai patinka kai yra su tavimi skaitomasi, atsiklausiama tavo nuomonès, o kaip tu darytum šitoje } \\
\text { situacijoje“. } \\
\text { „Praktiku metu slaugytojai labai geranoriškai bendrauja su studentais, palaikoma gera atmosfera“. }\end{array}$ \\
\hline $\begin{array}{l}\text { Slaugytojas (mentorius) } \\
\text { kaip mokytojas ir pagal- } \\
\text { bininkas }\end{array}$ & 29 & $\begin{array}{l}\text { „, Turèjau puikius mentorius, kurie nežemino, išklausè, padèjo, išmokino“. } \\
\text { „,Atèjome nieko nebandę, nieko nedarę praktiškai, todèl jautèmés labai pasimetę, tačiau mano mentoré } \\
\text { mokèjo tinkamai užmegzti ryši su studentais, todèl mane nuramino, supažindino“. } \\
\text { „Mentorès padrąsinimai, padèkojimai už pagalba“. }\end{array}$ \\
\hline $\begin{array}{l}\text { Galimybė atsakingai mo- } \\
\text { kytis }\end{array}$ & 20 & $\begin{array}{l}\text { „Praktika chirurgijos skyriuje, puiki praktika, tiek gerinant praktikos igüdžius, tiek lavinant ben- } \\
\text { dravimo ypatumus su pacientais“. } \\
\text { „Itvirtinau teorines žinias ir išbandžiau praktiškai“. }\end{array}$ \\
\hline $\begin{array}{l}\text { èkingumas ir } \\
\text { as }\end{array}$ & 19 & $\begin{array}{l}\text { „Pakelia savivertę tai, kad gatvèje einant sutinki pacientus, kuriuos slaugei ir jie tau dèkoja, atpa- } \\
\text { žista“. } \\
\text { „,Teigiamas pacientu požiūris i studenta (dèkingumas, studento laikymas profesionaliu)“. } \\
\text { „Po sunkios formos covid pacientu padèkos, laiškai“. }\end{array}$ \\
\hline $\begin{array}{l}\text { Galimybė padèti pacien- } \\
\text { tams }\end{array}$ & 18 & $\begin{array}{l}\text { „, Kuomet jaučiausi labiausiai padedanti žmonèms, kai užmegzdavau ryšį su pacientais ir nors jis } \\
\text { negalèjo kalbèti (nes buvo pažeistas kalbos aparatas) aš supratau ko jis nori iš jo mimiku, gestu, } \\
\text { küno kalbos“. } \\
\text { „Laiku sureagavau i paciento prašyma padèti prasidejus dūsimui ir laiku buvo suteikta pagalba iš } \\
\text { gydytoju ir personalo“. } \\
\text { „Paciento šeimos nariu liūdesio/nerimo mažinimas“. }\end{array}$ \\
\hline
\end{tabular}

2 lentelè. Neigiamos slaugos studentų patirtys profesinių praktikų metu.

\begin{tabular}{|c|c|c|}
\hline Kategorijos & $\mathbf{N}$ & Autentiški pasisakymai \\
\hline $\begin{array}{l}\text { Organizaciniai, psicho- } \\
\text { loginiai ir su studentų } \\
\text { sveikata susiję iššūkiai, } \\
\text { sąlygoti koronaviruso } \\
\text { infekcijos }\end{array}$ & 27 & $\begin{array}{l}\text { „,Susirgau Covid-19 nuo paciento, dèl praktikos atlikimo neturèjau pasirinkimo. Arba eiti rizikuot } \\
\text { savo ir artimuju sveikata, arba mesti mokslus“. } \\
\text { „Bendravimas su Covid-19 persirgusiais, kuriuos mačiau sveikus praktikos pradžioje ir jos pabai- } \\
\text { goje“. Žmonès nusikankinę, nenori kai kurie net gyventi“. } \\
\text { „Infekcijos nepavyko išvengti, susirgau ir aš. Dèl savęs nejaučiau streso, nors ir sunkiai sirgau, } \\
\text { labiausiai jaudinausi dèl artimuju“. } \\
\text { „,Kai teko dèveti apsauginę apranga } 16 \text { h nenusirengiant, buvo labai sunku, viska skaudèjo“. }\end{array}$ \\
\hline $\begin{array}{l}\text { Mirštantys ir sunkiai ser- } \\
\text { gantys (nepagydoma liga) } \\
\text { pacientai }\end{array}$ & 21 & $\begin{array}{l}\text { „Mirštantis žmogus, kuomet teko gaivinti, tačiau stengtis išlikti ramiai“. } \\
\text { „Jaunos moters mirtis“. } \\
\text { „Paciento staigi mirtis ir gaivinimas. Tai labai paveike mastyma apie žmogaus gyvybe, tačiau pa- } \\
\text { rodè, kaip esant tokiai situacijai, medicinos personalas susivienija ir viska atlieka kaip viena didele } \\
\text { komanda“. } \\
\text { „Kai ateini ì praktika pirma diena ir atsitinka situacija, kai miršta žmogus ar kokia kita neeilinè } \\
\text { situacija ir tave bando siuntinèti atnešti to ar ano, kai nežinai, kur kas padèta“. }\end{array}$ \\
\hline $\begin{array}{l}\text { Nemalonus personalo el- } \\
\text { gesys su studentais }\end{array}$ & 18 & $\begin{array}{l}\text { „Padedame slaugytojams, tačiau jos nevertina mūsų pagalbos ir dar sugeba priekaištauti, kelti balsa } \\
\text { ir kitaip negražiai bendrauti“. } \\
\text { „Kai atèjau pirma diena i praktika, pasisveikinau ir negavau jokio atsakymo, tik klausima, kiek čia } \\
\text { laiko büsiu. Ir buvau nusiųsta sèdèti viena ị kita kabineta“. }\end{array}$ \\
\hline $\begin{array}{l}\text { Pikti ir studentais nepasi- } \\
\text { tikintys pacientai }\end{array}$ & 7 & $\begin{array}{l}\text { „Kai pacientas su tavim negražiai, piktai bendrauja arba išreiškia nepasitenkinima, o tu tiesiog } \\
\text { sukandęs dantis turi šypsotis“. } \\
\text { „Buvau aprèkta pacientès dèl kūno temperatūros matavimo dažnumo ir rankų dezinfekcijos, bandžiau } \\
\text { paaiškinti situacija, bet moteris visiškai negirdejo manęs“. }\end{array}$ \\
\hline
\end{tabular}


edukacine mentoriaus parama, galimybe atsakingai dirbti ir mokytis, pacientų dèkingumu ir pasitikèjimu studentais, galimybe padèti žmogui, pagerinti jo sveikatą (1 lentelè). Studentai pasitikejjimą vertina ir supranta kaip gerai atlikto darbo pripažinimą „Slaugytojo pasitikejjimas mano atliktu darbu“. Pasitikejjimas gali būti išreikštas motyvuojant studentus ateityje likti dirbti praktikos atlikimo vietoje „Darbo pasiūlymai < ..> ieškant naujo komandos nario“ ar parengiant jiems padèkos raštus , ,<...net atsiunte padèkos laišką praktikų vadovui...>".

Slaugytojų mentorių vaidmenị studentai išryškina kaip pozityvų profesinès veiklos praktikos momentą, kai juos išklauso, nežemina, pataria, nuramina, padrąsina. Tai iliustruoja šie slaugos studentų pasisakymai: „<...jautėmès labai pasimetę, tačiau mano mentore mokèjo tinkamai užmegzti ryšį su studentais, todèl mane nuramino... >“, ,<..mentorès padrąsinimai, padèkojimai...>“.

Slaugos studentai profesines praktikas vertina kaip galimybę tobulinti teorines žinias, jas pritaikyti praktiškai: „Puiki praktika, tiek gerinant praktikos igūdžius, tiek lavinant bendravimo ypatumus su pacientais“.

Tyrime dalyvavusiems slaugos studentams svarbus pacientų pasitikejjimas jais: „, ,..einant sutinki pacientus, kuriuos slaugei ir jie tau dèkoja, atpažįsta...>“, , , $\ldots$ Covid pacientu padẻkos, laiškai...>“"

Galimybè padèti sergančiajam, prisidèti prie jo sveikatos gerovès minima tyrime dalyvavusių slaugos studentų pasisakymuose: , , $<$...nors jis negalejo kalbèti (nes buvo pažeistas kalbos aparatas), aš supratau, ko jis nori iš jo mimikų, gestų, kūno kalbos...>“", ,<...laiku sureagavau i paciento prašymą padèti prasidèjus dusimui...>“.

Slaugos studentų dažniausios neigiamos situacijos buvo akistata su pacientų mirtimi ir sunkiai sergantys pacientai, personalo nepasitikejjimas studentais, jų menkinimas.

Kokybinių duomenų analizė parodè, kad organizaciniai, psichologiniai ir su studentų sveikata susiję koronaviruso infekcijos keliami iššūkiai buvo minimi tik antrojo tyrimo metu: ,_...susirgau Covid-19 nuo paciento...>“, , ,...teko dèvèti apsauginę aprangą $16 \mathrm{~h}$ nenusirengiant, buvo labai sunku... >“.

Neigiamus jausmus, leidžiančius giliau pažvelgti i žmogaus būtị, sukèlè situacijos, susijusios su mirštančiais ir sunkiai sergančiais pacientais: „, „..tai labai paveikè mąstymą apie žmogaus gyvybę, tačiau parodè, kaip esant tokiai situacijai, medicinos personalas susivienija... $>$ “,, ,...kuomet teko gaivinti, tačiau stengtis išlikti ramiai... >“.

Slaugos studentai atvirai pasidalino situacijomis, kuriose personalo elgesys ir bendravimas jiems pasirodè nemalonus: $<$...nevertina mūsų pagalbos ir dar sugeba priekaištauti, kelti balsą ir kitaip negražiai bendrauti...>".
Pasitaikè keli atvejai, kai slaugos studentai jautè pacientų pyktị ir pasitikejjimo stoką „, „...buvau aprèkta pacientės dèl kūno temperatūros matavimo dažnumo ir rankų dezinfekcijos...>.

\section{Išvados}

1. Slaugos studentų stresas yra dažnas reiškinys, susijęs su įvairiomis organizacinėmis profesiniu praktikų atlikimo situacijomis, bendravimu su personalu ir pacientais. Šios streso priežastys vienodai aktualios tiek iki koronaviruso pandemijos, tiek ir jos metu. Tačiau pandemijos laikotarpiu stresą kèlè situacijos, tiesiogiai susijusios su koronaviruso pandemija: ignoruojamas slaugytojų vaidmuo socialinèse medijose bei baimè užsikrèsti koronavirusu.

2.Atlikta kokybinių duomenų turinio analizè išryškino teigiamas ir neigiamas profesinių praktikų situacijas, kurios yra ypač svarbios slaugos studentu psichosocialinei adaptacijai ir profesinių kompetenciju ịijimui praktinio mokymo metu realioje darbo vietoje. Teigiamos situacijos: pasitikèjimas studentais ir jų pripažinimas, mentorių ir kitų darbuotojų dėmesys ir mokymas, galimybė atsakingai dirbti ir mokytis, pacientų dèkingumas ir pasitikejjimas studentais, galimybè padèti žmogui, pagerinti jo sveikatą. Slaugos studentų dažniausios neigiamos situacijos buvo akistata su pacientų mirtimi, sunkiai sergantys pacientai, personalo nepasitikejjimas studentais, jų menkinimas, užsikrètimo COVID-19 liga baimè.

\section{Literatūra}

1. La Sala R, Ruozi C, Gavagni S, Martelli M, Marletta G, Primosa F. Nursing students' perception of the quality of clinical learning: a mixed methods inquiry. Acta Biomed 2019;90(6S):78-86.

2. Ayaz-Alkaya S, Yaman-Sözbir Ş, Bayrak-Kahraman B. The effect of nursing internship program on burnout and professional commitment. Nurse education today 2018;68:19-22.

https://doi.org/10.1016/j.nedt.2018.05.020

3. Bhurtun HD, Azimirad M, Saaranen T, Turunen H. Stress and coping among nursing students during clinical training: An integrative review. Journal of Nursing Education 2019;58(5):26672.

https://doi.org/10.3928/01484834-20190422-04

4. Rabei S, Mourad G, Hamed AE. Work stress and sleep disturbances among internship nursing students. Middle East Current Psychiatry. 2020;27(1):1-6.

https://doi.org/10.1186/s43045-020-00032-1

5. Piscalkiene V, Navickiene L. General practice nursing students' stress during professional internship: causes and stress coping methods. Sveikatos mokslai/Health sciences in Eastern Europe 2020;30(6):143-151. 
https://doi.org/10.35988/sm-hs.2020.156

6. Gurková E, Zeleníková R. Nursing students' perceived stress, coping strategies, health and supervisory approaches in clinical practice: a Slovak and Czech perspective. Nurse education today 2018;65:4-10.

https://doi.org/10.1016/j.nedt.2018.02.023

7. Hopkins M, Fetherston CM, Morrison P. Aggression and violence in healthcare and its impact on nursing students: A narrative review of the literature. Nurse education today 2018;62:158-163. https://doi.org/10.1016/j.nedt.2017.12.019

8. Kim Y, Park H, Hong SS, Chung HJ. Effects of a neonatal nursing practice program on students' stress, self-efficacy, and confidence. Child Health Nursing Research 2018;24(3):319-28. https://doi.org/10.4094/chnr.2018.24.3.319

9. Alkhawaldeh JF, Soh KL, Mukhtar FB, Peng OC, Anshasi HA. Stress management interventions for intensive and critical care nurses: A systematic review. Nursing in critical care 2020;25(2):84-92.

https://doi.org/10.1111/nicc.12489

10. Aghaei N, Babamohamadi H, Asgari MR, Dehghan-Nayeri N. Barriers to and facilitators of nursing students' adjustment to internship: A qualitative content analysis. Nurse Education Today 2021;99:104825.

https://doi.org/10.1016/j.nedt.2021.104825

11. Aslan H, Pekince H. Nursing students' views on the COVID-19 pandemic and their percieved stress levels. Perspectives in psychiatric care 2021;57(2):695-701.

https://doi.org/10.1111/ppc.12597

12. Ulenaers D, Grosemans J, Schrooten W, Bergs J. Clinical placement experience of nursing students during the COVID-19 pandemic: A cross-sectional study. Nurse education today 2021;99:104746. https://doi.org/10.1016/j.nedt.2021.104746

13. Eweida RS, Rashwan ZI, Desoky GM, Khonji LM. Mental strain and changes in psychological health hub among internnursing students at pediatric and medical-surgical units amid ambience of COVID-19 pandemic: A comprehensive survey. Nurse Education in Practice 2020;49:102915.

https://doi.org/10.1016/j.nepr.2020.102915

\section{STRESS OF NURSING STUDENTS DURING INTERNSHIP BEFORE AND DURING THE COVID-19 PANDEMIC}

\section{Piščalkienė, L.Navickienė}

Keywords: stress, coronavirus pandemic, Covid-19, nursing students, internship.

Summary

Research shows that during the internships nursing students experience stress which varies from moderate to high level.
Although stress is a normal reaction to many circumstances, its effects can be detrimental to health, learning outcomes, students 'self-esteem, and motivation to pursue nursing studies.

The aim of the study was to compare the causes of stress among nursing students during and before the COVID-19 pandemic.

Research object and methods. To achieve the study aim two surveys were conducted. The first survey took place before the COVID-19 pandemic (November and December 2019). The second survey was conducted during Covid -19 pandemic (November and December 2020). For the study quantitative and qualitative data were collected. The development of the research instrument was based on three main areas of stressors: 1) organizational conditions of professional practice; 3) communication; 4) situations related to coronavirus infection and its management (this area of stressors was assessed only during the second survey).

Qualitative data were collected by asking students an open-ended question about the positive and negative experiences during the internships that can be described as conditions that reduce or increase stress level.

The participants of the study were students from the college sector studying in the general practice nursing study program. A total of 290 second-, third- and fourth-year students from one Lithuanian college general practice nursing study program participated in the study.

Results. Stress among nursing students is a common phenomenon related to a variety of organizational internship situations, interactions with staff, and patients. These causes of stress were equally relevant before and during the coronavirus pandemic. However, during the pandemic, the stress was raised by situations directly related to the coronavirus pandemic: the ignored role of nurses on social media and the fear of becoming infected with coronavirus.

Analysis of qualitative data has highlighted the positive and negative situations during professional practices, which are particularly important for the psychosocial adaptation of nursing students and the acquisition of professional competencies during practical training in the real workplace. Positive situations: trust and recognition of students, mentors and other staff members' attention and training, the opportunity to work and learn responsibly, the appreciation and trust of patients in students, the opportunity to help and improve patients' health. The most common adverse situations among nursing students were the following: facing patients' death, severely ill patients, staff distrust of students, humiliation, fears associated with COVID-19 disease.

Correspondence to: viktorija.piscalkiene@go.kauko.lt

Gauta 2021-11-11 